\title{
Bank performance variability and strands of inflationary conditions
}

\author{
Rexford Abaidoo \\ University of Maryland Eastern Shore, Princess Anne, Maryland, USA, and \\ Hod Anyigba \\ Nobel International Business School, Accra, Ghana
}

\begin{abstract}
Purpose - This study seeks to examine the extent to which strands of inflationary related conditions (inflation expectations, inflation uncertainty and realized inflation); macroeconomic uncertainty and the likelihood of recessionary conditions influence performance indicators in the US banking sector over a specified time period.

Design/methodology/approach - The study adopts seemingly unrelated regression model (SUR) advanced by Zellner (1962) in its examination of how specific strands of inflationary conditions, and other adverse macroeconomic conditions influence performance dynamics in the US banking sector.

Findings - Empirical evidence suggest that among various adverse macroeconomic conditions examined, inflation expectations and macroeconomic uncertainty tend to have significant constraining impact on key performance indicators in the US banking sector than other conditions examined. Comparatively, this study finds that inflation expectations and macroeconomic uncertainty tend to have much more constraining impact on return on equity, than on return on assets in the US banking sector. Results further suggest that among the three bank performance indicators examined, net interest margin is the least vulnerable bank performance indicator to various adverse macroeconomic conditions examined in the study.

Practical implications - Apart from the various empirical results noted above, this study's findings are projected to help inform strategic planning decisions among institutions in the banking sector. The various findings could, for instance, inform policies and operational strategies geared toward reducing vulnerability associated with specific performance indicators such as return on equity. This reduction could be achieved by critically examining how the various performance indicators react to individual adverse macroeconomic conditions examined in this study. The process could ultimately help in developing tailored measures/ procedures aimed at reducing how susceptible key performance indicators are to the various adverse macroeconomic conditions. This study's findings could also provide the platform for more adaptive policies aimed at minimizing the effects of noted macroeconomic conditions on operational efficiency in the banking sector.

Originality/value - The uniqueness of this study, compared to related ones found in the literature, stems from its treatment of three variant of related strands of macroeconomic condition (different variant of inflationary conditions) in the same framework in its empirical analysis.
\end{abstract}

Keywords Adverse macroeconomic conditions, Bank performance, Seemingly unrelated regression

Paper type Research paper

\section{Introduction}

The fundamental view that macroeconomic conditions influence bank operational activities and performance dynamics is not new to the finance and economics literature. Significant number of empirical studies focusing on this interaction (how macroeconomic conditions influence activities of financial institutions), such as Moguillansky (2002); Demir (2009), etc.

\section{JEL Classification - E32, E44, F62, G21}

(C) Rexford Abaidoo and Hod Anyigba. Published in European Journal of Management and Business Economics. Published by Emerald Publishing Limited. This article is published under the Creative Commons Attribution (CC BY 4.0) licence. Anyone may reproduce, distribute, translate and create derivative works of this article (for both commercial and non-commercial purposes), subject to full attribution to the original publication and authors. The full terms of this licence may be seen at http:// creativecommons.org/licences/by/4.0/legalcode
The US banking sector

Received 28 September 2018 Revised 21 June 2019 21 November 2019 29 January 2020 Accepted 3 August 2020

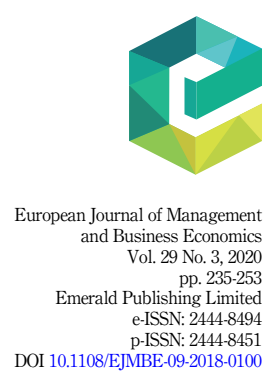


EJMBE 29,3 have reported divergent conclusions on how various macroeconomic conditions influence specific performance indicators among financial institutions such as banks. Despite extensive existing literature on this ever-evolving link, the relationship continues to engender significant interest due to transient and often unpredictable nature of most macroeconomic conditions. This growing interest (focus on how macroeconomic conditions influence bank performance) has been attributed to two core factors according to reviewed literature. The first is the continuous need to be abreast with evolving effects of such macroeconomic conditions on bank profitability for strategic planning in a highly competitive business environment. The second rationale revolves around the need to periodically evaluate potential inimical impact such macroeconomic conditions may have on operational activities in order to reduce operational vulnerability to such conditions. For most firms and financial institutions such as banks, this second objective is often achieved through measures specifically designed to make operational activities more resilient to various macroeconomic conditions. Unlike most of the related literature focusing on the dynamic relationship between macroeconomic conditions and performance in the banking sector, this study is designed to have relatively narrow focus in its empirical assessment. Specifically, we seek to examine the extent to which strands of inflationary related conditions (inflation expectations, inflationary uncertainties and realized inflation), macroeconomic uncertainty and the likelihood of recessionary conditions impacts selected performance indicators in the US banking sector. In order words, apart from effects of macroeconomic uncertainty on banking sector performance, which one could readily find examples in the literature, we also examine the extent to which the likelihood of recessionary conditions and combined effects of strands of inflationary related conditions influence variability in specific banking sector performance indicators in the US economy.

\subsection{The case for the study}

Reviewed empirical studies (examples presented in literature review) suggest that operational efficiency and performance among financial institutions such as banks are shaped by both industry-specific and external macroeconomic factors. This study subscribe to this view because significant empirical studies exist in the literature in support of such position. However, conclusions in the present literature notwithstanding, we presents an alternative view. We hypothesize that although industry-specific factors such as bank size, ownership structure, etc. (Akhavein et al. (1997); Smirlock (1985); Athanasoglou et al. (2008); Heffernan and $\mathrm{Fu}$ (2008)) are integral in bank performance assessments, prevailing/ anticipated macroeconomic conditions may explain relatively more of the fluctuations in such performance. In order words, although industry-specific factors play a crucial role in determining performance among financial institutions such as banks, we are of the view that exogenous nature of macroeconomic conditions (the fact that firms have relatively less control) may make such conditions more central to performance dynamics all things being equal. This position stems from the assumption that ordinarily financial institutions such as banks have some measure of operational control in dealing with industry-specific factors; however, the same cannot be said of a much broader macroeconomic condition such as recession. Again, although we agree with various empirical conclusions about the importance of industry-specific factors in bank performance, we surmise that broader prevailing or anticipated macroeconomic conditions might have more influence on such performance. In order words, as crucial as industry-specific factors are, bank performance dynamics may depend more on how resilient such institutions are to a more pervasive external macroeconomic shocks all things being equal. In addition, unlike industry-specific factors, which often affords banks some reasonable preemptive choices, random and unpredictable nature of most adverse macroeconomic conditions often puts banks in a reactionary mode despite best forward-looking strategies. 
The uniqueness of this empirical review revolves around its examination of three variant of inflationary conditions in the same empirical framework. Ongoing debate on the relationship among these three strands of inflationary conditions suggests that the conditions might have divergent effect on key performance indicators all things being equal. For instance, there is a growing view that inflationary uncertainty might be more inimical to institutional performance than inflation expectations since the former tend to make such entities more vulnerable due to vague signals to inform strategic planning. Reviewed literature further suggests that this inquiry might be the first to examine the combine effects of such related strands of macroeconomic conditions (inflation expectations, inflation uncertainty and inflation) in a framework focusing on performance in the banking sector. Apart from the core objective of the study, the approach adopted will also allow us to identify the underlying interactions among various macroeconomic variables, and how they ultimately affect performance indicators in the US banking sector.

The following questions largely defines the scope and structure of various analysis pursued in this empirical study. (1) Are the various adverse macroeconomic conditions significant in explaining fluctuations in key bank performance indicators? (2) Are there empirically significant variations in how strands of related adverse macroeconomic conditions affect bank performance indicators? Finally, (3) a determination of macroeconomic condition influencing much of the variability in reviewed banking sector performance indicators. The rest of the study is structured as follows; the next section reviews historical trend in the US banking sector performance, focusing on the three performance indicators. This is followed by a critical examination of strands of inflationarylinked conditions. Section three reviews relevant literature on structure of the US banking sector, examination of relationships between bank performance and various macroeconomic conditions in the study, and an overview of the bank profitability literature in general. Sources of data and empirical methodology adopted are presented in subsequent sections. Empirical tests and analysis of the results are presented in the final sections. The study concludes with a review of major findings and potential policy implications.

\section{Historical trends in the US banking sector performance}

This section critically examines key bank performance indicators over the period captured in the study. The goal is to illustrate graphically the historical performance trend associated with each performance indicator over the study period and verify if such trends reflect any notable macroeconomic conditions over the same period. Banking sector performance indicators examined are divided into two categories; profitability indicators measured by return on assets (ROA) and return on equity (ROE) and a proxy for operational efficiency using net interest margin (NIM).

\subsection{Return on asset (ROA)}

Figure 1 below illustrate historical performance features associated with ROA among the US banks over the period captured in the study. A critical examination of Figure 1 suggests that over the study period, there were two major significant periods of decline in return on assets in the US banking sector. The first of such decline was recorded in the second quarter of 1987, when ROA in the US banking sector recorded a percentage change of $-0.37 \%$. After this period, the trend improved significantly, but continued to fluctuate with a positive trend until the fourth quarter of 2006, when ROA experience another sharp decline from a peak of $1.35 \%$. This second declining trend persisted until the fourth quarter of 2009 with a recorded lowest decline of $-0.10 \%$ before the trend experienced another upward trend. A key noticeable feature associated with ROA trend over the period under consideration is its responsiveness 
EJMBE 29,3

\section{8}

Figure 1.

Trends in return on assets
Return on Assets: US Banks (1984-2016)

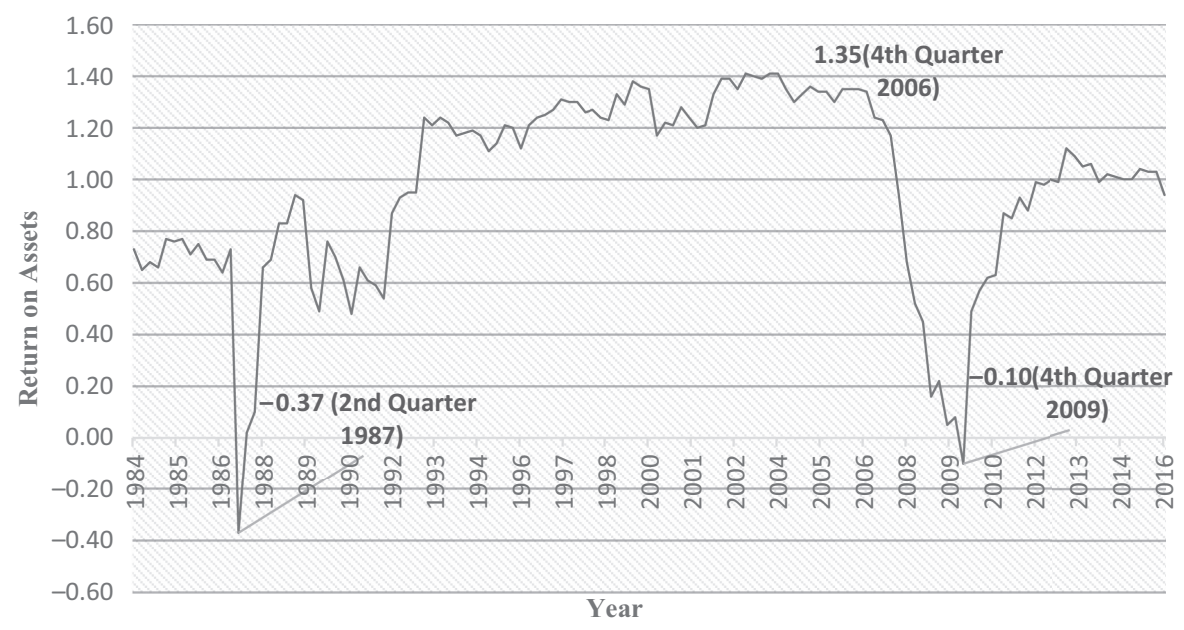

to a notable macroeconomic condition over the same period. Critical examination of conditions during this period suggests that the decline in trend coincided with recent recessionary condition brought about by the US mortgage crisis. This simultaneous movement in decline in ROA and the recent recession in the US economic history to some degree suggest that macroeconomic condition such as recessionary environment tend to have significant negative influence on banking sector performance (ROA), all things being equal. This phenomenon to some extent lends support to the projection that adverse macroeconomic could account for significant fluctuations in performance in the banking sector.

\subsection{Return on equity (ROE)}

Historical performance characteristics associated with return on equity, the second banking sector performance indicator examined, to some degree mimic similar trajectory exhibited by ROA in terms of how the performance indicator fluctuates given similar macroeconomic conditions. However, in this instance, observed percentage change in how the performance indicator fluctuates over time is comparatively higher. Figure 2 suggests that ROE trend in the US banking sector also declined significantly during the recent recessionary period; a condition, which further supports the preposition that undesirable macroeconomic conditions could, all things being equal, have a significant constraining impact on banking sector performance.

\subsection{Banking sector efficiency: net interest margin}

Compared to the first two bank performance indicators discussed, net interest margin is employed as a proxy for efficiency in the US banking sector. The use of net interest margin (NIM), as a proxy for bank operational efficiency or bank efficiency, follows existing empirical precedents and suggestions from related studies. Demirguc-Kunt and Huizinga (1999); Vensel et al. (2004); Sidabalok et al. (2011); Marinković and Radović (2014) and Angori et al. (2019) have either employed NIM as a measure of bank efficiency or alluded to it as being a good proxy for bank efficiency. Figure 3 below suggests that this performance indicator is characterized by historical trend conditions that are significantly distinct from those 

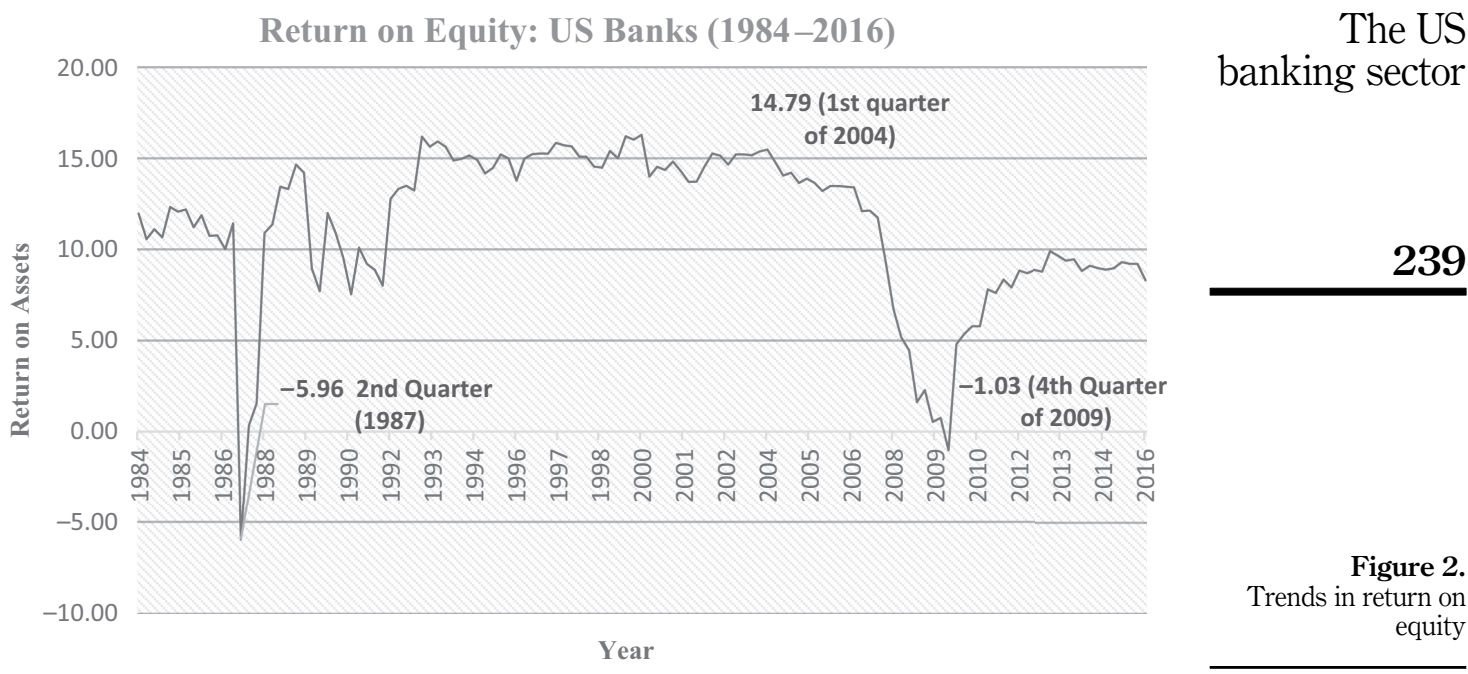

Figure 2.

Trends in return on equity

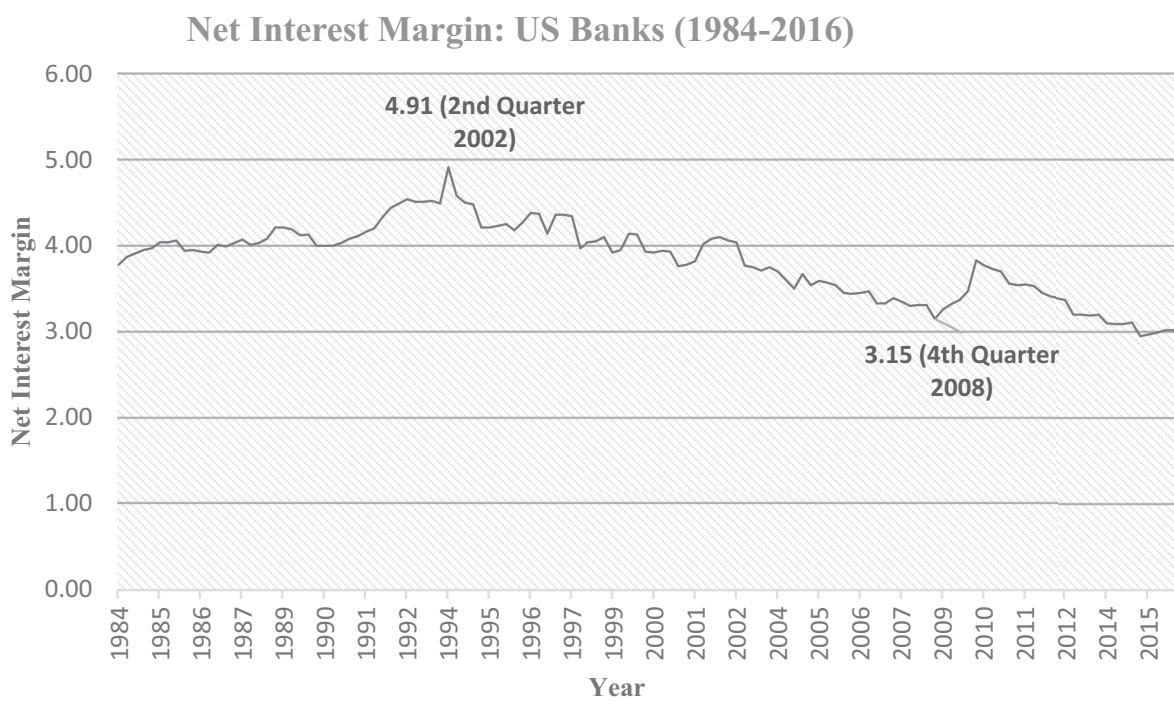

Figure 3. Trends in net interest margin

experienced by return on assets and return on equity over the same period. For instance, between 1984 and 2002, while both return on assets and return on equity were characterized by extreme volatility, NIM according to Figure 3, rather experienced appreciable growth over the period. In addition, NIM seemed not have been significantly by the recent recessionary condition which devastated other profitability indicators discussed above over the same period. Figure 3 suggests that NIM over the period averaged over $3 \%$ with relatively minimal volatility compared to the first two performance indicators. These divergent trend features exhibited by the three performance indicators to some degree suggest that significant differences may exist in how these key performance indicators respond to various macroeconomic conditions; a feature we seek to verify empirically in subsequent sections. 
EJMBE 29,3

\section{0}

\section{Inflation, inflation uncertainty and inflation expectations}

This section examines strands of related macroeconomic conditions employed in subsequent empirical analysis. The first of these conditions is inflation; this macroeconomic condition defines percentage change in a specific price index. Theoretically, inflationary condition affects the value of financial assets and other financial instruments in a bank's portfolio and ultimately the return accruing on such assets over time. Inflationary condition, for instance, could affect the value of investment returns and for that matter overall profitability or performance all things being equal. In addtion, inflationary conditions have also been shown to influence variability in the value of bank assets holdings and operational efficiency. Given this theoretical link on how bank's assets value could be impacted by inflationary pressures, we project that inflation could negatively influence assets base of banks and ultimately, overall performance.

Compared to inflation, inflation uncertainty, the second related macroeconomic variable examined, rather captures perceived ambiguity about potential inflationary conditions instead of the actual condition as defined above. We project that this macroeconomic condition (inflation uncertainty) could affect investment performance in the US banking sector because the condition can affect potential for realizing expected returns or performance projections. The last of the inflation-related conditions, inflation expectations, capture a scenario where banks or financial institutions anticipate inflationary conditions due to ongoing or impending policy decisions or macroeconomic conditions. The extent to which inflation expectations may influence performance indicators in the US banking sector revolves around the assumption of rational behavior on the part of banks as economic agents. We postulate that if banks subscribe to assumption of rational expectations theory where all available information including relevant expectations inform present decisions and operational strategy; then inflation expectations may have significant impact on bank operational activities and ultimately key performance indicators all things being equal. It is important, however, to point out a marked difference between inflation uncertainty and inflation expectations variables. The key difference between the two macroeconomic conditions revolves around how signals on changes in future price levels (inflation) are interpreted by economic agents or entities such as banks. A much clearer signal attesting to an impending significant change in a price index or increases in general price levels constitutes inflation expectations; however, a distorted or vague signal about potential inflationary condition leads to inflation uncertainty. We project that these variants of inflationary conditions could have divergent impact if any on selected bank performance indicators. Table 1 summarizes projected effects of the various macroeconomic variables namely, macroeconomic uncertainty, inflation uncertainty, recession probability, inflation expectations and inflation on ROA, ROE and NIM.

\section{Literature review}

\subsection{The US banking sector}

According to the Federal Reserve Bank of St. Louis, the US banking system currently consists of more than 4,605 commercial banks and other authorized deposit-taking institutions. These commercial banks have the Federal Reserve System as the country's central bank. There are 12 Federal Reserve Banks at the apex of the US banking system, each task with the coordination of activities in different regions of the US economy. The Federal Reserve is responsible for monetary policies, maintaining stability of the financial system, etc. with the ultimate goal of price stability and sustaining confidence in the US financial and banking system. Apart from the Federal Reserve at the apex, the US banking system also features the Federal Deposit Insurance Corporation (FDIC), which was established in 1933 in responds to several bank failures prior to that year. The FDIC was set up to "preserves and promote public 
Macroeconomic variable

Bank performance indicator

Return on assets

Macroeconomic uncertainty

Inflation uncertainty

Recessionary probability

Inflation expectations

Inflation

Return on equity

Macroeconomic uncertainty

Inflation uncertainty

Recessionary probability

Inflation expectations

Inflation

NIM (proxy for Bank Efficiency)

Macroeconomic uncertainty

Inflation uncertainty

Recessionary probability

Inflation expectations

Inflation
Projected effects

\section{banking sector}

Negative

Negative

Negative

Negative

Negative

241

Negative

Negative

Negative

Negative

Negative

Positive

Positive

Positive

Positive

Positive
Table 1.

Summary of projected effects of various macroeconomic variables on bank performance indicators

confidence in the US financial system by insuring deposits in banks and thrift institutions for at least \$250,000; by identifying, monitoring and addressing risks to the deposit insurance funds; and by limiting the effect on the economy and the financial system when a bank or thrift institution fails". In responds to ever-present threats to the finance and banking sector, the US government has since the 1980s implemented a number of banking sector reforms that are geared toward safeguarding and improving the banking sector to ensure sustained consumer and investor confidence. These reforms notwithstanding, the US banking sector continue to grapple with occasional challenges. These challenges include persistent low interest rates, increasing nonperforming asset among financial institutions, relatively weak economic growth and fiscal and trade policy uncertainties. The US banking sector also continues to contend with the threat of financial market contagion effects from other dominant financial markets due to growing integration of global financial markets. The most significant incident that characterized the US banking sector in recent years was the 2007 financial crisis brought about by the failure of the mortgage sub-market of the US economy. This crisis exposed some of the risky and illegal investment practices pursued by some banks and financial institutions. Some banks and financial institutions failed or were acquired in the process because of the financial crisis; notable among these were Wachovia Bank, Lehman Brothers, Bear Stearns, etc. The failure of these banks and financial institutions generated renewed call for proper monitoring of the activities of the US financial and banking system and the need for new and more stringent code of conduct on operational activities in the banking sector. This call culminated in the introduction of the Dodd-Frank Wall Street Reform and Consumer Protection Act (Public Law 111-203) enacted by the US Congress in 2010. The act was signed into federal law on July 21, 2010. This act brought about the most significant changes to financial regulation in the US banking sector since the regulatory reform after the Great Depression.

\subsection{Inflation, inflation uncertainty, inflation expectations and bank performance}

Relationships between some of the explanatory variables examined and bank performance have been reviewed in different formats in the existing literature. A critical overview of 
EJMBE 29,3 related literature suggests that among the various explanatory variables examined in this context; inflation has received the most extensive empirical examination compared to the others in terms of how the condition impact profitability and performance in general. Our review suggests that comprehensive empirical examination focusing on the link between inflation uncertainty and key bank performance indicators are rare. In fact, we fail to identify any study specifically examining the relationship we seek to examine. In addition, a thorough review also suggests that the literature is limited in terms of how inflation expectations influence specific bank performance indicators. This empirical inquiry hopes to fill this gap in its examination of how aforementioned macroeconomic conditions influence key bank performance indicators in the US banking sector.

Among studies focusing on how inflationary conditions affect key bank performance indicators, Saeed (2014) found evidence suggesting that inflation has negative impact on key bank performance indicators such as ROA and ROE. In addition, in an earlier study, Bourke (1989) also found evidence alluding to negative relationship between inflation and bank profitability. Sufian and Chong (2008), Ayaydin and Karakaya (2014), Francis (2013) further provide evidence suggesting significant negative relationship between measured inflation (CPI) and bank profitability under varied conditions. Again, in a related study focusing on the relationship in question, Bordeleau and Graham (2010) further surmised that because operational activities of banks require that they lend money for longer periods than they borrowed, inflation as a macroeconomic condition tends to have negative impact by decreasing margins and profits.

Apart from the above studies alluding to negative relationship between inflation and key bank performance indicators, review of the literature suggest that significant empirical work exists suggesting a positive association between inflation and some bank performance indicators. Khan et al. (2014), for instance, found significant association between inflation and bank performance indicators such as ROA, ROE and NIM. Guru et al. (2002) also showed that inflation, as a macroeconomic condition tend to have positive impact on bank profitability and performance. In a study by Tan and Floros (2012) in which the role of inflation in bank performance was examined, the outcome further pointed to a positive association between inflation, bank profitability, cost efficiency, etc. in the Chinese economy. Pasiouras and Kosmidou (2007), in an earlier study also found evidence of positive association between inflation and profitability among a nation's domestically-owned banks. A positive association between inflation and bank performance or profitability was also found in the following studies: Athanasoglou et al. (2008); Flamini et al. (2009) and Garcia-Herrero et al. (2009), respectively. This succinct review of related studies to some extent point to divergent effects inflationary conditions tend to have on bank performance indicators and operational activities.

\subsection{Macroeconomic uncertainty, recession probability and bank performance}

Apart from the role inflationary linked conditions play in bank performance reviewed above, augmented roles of macroeconomic uncertainty and recession expectations on banking sector performance are also examined. Reviewed literature on this relationship suggests that macroeconomic uncertainty all things being equal, tend to constrain or have negative impact on bank performance. For instance, in a study focusing on this association, Nier and Zicchino (2005) concluded that in economic downturns (macroeconomic uncertainty) banks tend to experience significant losses. In addition, Baum et al. (2005) further showed that macroeconomic uncertainty tends to distort efficient allocation of funds to potential borrowers. In order words, macroeconomic uncertainty was found to be inimical to operational efficiency in terms of loan management; a condition, which might influence bank performance since it affects the ability to make strategic decisions pertaining to risk 
characteristics of borrowers and investments. This conclusion by Baum et al. is consistent with fundamental economic argument suggesting that macroeconomic uncertainty distorts forecast signals and frustrates strategic planning making it difficult to operate at the optimal level of performance. Talavera et al. (2006), who investigated effects of macroeconomic uncertainty on bank lending behavior in Ukraine further found evidence of a negative relationship between bank loan to capital ratio and macroeconomic uncertainty.

A review of the literature on the extent to which the likelihood of recession or recession probability influence bank performance found no empirical study that has specifically examined the relationship. We postulates that all things being equal, the likelihood of recession may generate some form of bank operational efficiency in the short run because of presumed rational need to shore-up operational structures to reduce vulnerability to recessionary shocks. In order words, the likelihood of recession though an adverse macroeconomic condition has the potential to exert positive impact on a bank's operational performance (NIM). However, the same macroeconomic condition (recessionary expectations) could have a negative impact on profitability indicators such as ROA, etc. in the long run.

\subsection{General overview of bank profitability literature}

Available literature presents significantly varied conclusions on factors explaining variability in bank profitability/performance. These factors as already alluded to span industry specific factors to conditions or factors in the general business or macroeconomic environment. For instance, in a recent empirical inquiry focusing on bank performance in China, Fang et al. (2019) showed that cost efficiency, profit efficiency, inflation and bank size are the main factors explaining variability in bank profitability. In addition, in a related study examining determinants of bank profitability in European Union, Petriaa et al. (2015) found that credit and liquidity risk, management efficiency, business diversification, competition and economic growth are the main factors having significant impact on bank profitability. In a similar study focusing on dynamics of bank profitability in Vietnam, Batten and Xuan Vinh Vo (2019) further concluded that both industry specific and macroeconomic factors tend to have significant effects on bank profitability. Aburime (2008), in an earlier study, reports that real interest rates, inflation, prevailing monetary policy and exchange rate regime are the significant factors explaining fluctuations in bank profitability in the Nigerian economy. A panel data study focusing on commercial banks in India by Al-Homaidi et al. (2018) further showed that variety of both industry specific and macroeconomic factors are the main determinants of commercial bank profitability. Kohlscheen et al. (2018), who examined core factors influencing bank profitability among emerging markets, concluded that bank profitability is positively related to bank specific credit growth and long-term interest rate; but negatively related to short-term interest rate. The study further noted the crucial role economic growth play in bank profitability. Sahyouni and Wang (2018) in a related study also alluded to the significant role of both industry specific factors and macroeconomic conditions play in explaining fluctuations in bank profitability. For instance, Sahyouni and Wang (2018) showed that asset management, bank size, capital ratio, credit quality and operating efficiency have divergent significant impact on bank profitability. This overview highlights spectrum of factors and conditions found to explain variability in bank profitability or performance. None of these studies, however, examined the three strands of inflation related conditions examined in the present study.

\section{Data, variables and model specification}

Empirical tests performed in this inquiry use data from the US Federal Reserve Economic database (Fred). Quarterly time series data used in subsequent empirical analysis span the 
EJMBE 29,3

period between the first quarter of 1984 and the first quarter of 2016. The data are made up of the following variables; inflation (Infl), inflation expectations (Inflexp), inflation uncertainty (Influnc), recession expectations (Recexp) and macroeconomic uncertainty (Macrounc) as the main explanatory variables. Dependent variables capturing the US banking sector performance (namely, ROA, ROE and NIM are also sourced from the same database. With the exception of inflation uncertainty and macroeconomic uncertainty that are derived through an econometric process, all other variables exist as absolute indicators in the Fred database.

\subsection{Deriving inflation uncertainty and macroeconomic uncertainty variables}

Following studies such as Bekaert and Harvey (1997); Aggarwal et al. (1999); Akgül and Sayyan (2005); Gokbulut and Pekkaya (2014), inflation uncertainty and macroeconomic uncertainty variables are derived using generalized autoregressive conditional heteroskedastic framework $G A R C H(1,1)$ originally submitted by Bollerslev (1986) as a generalization of Engle (1982) ARCH framework. A GARCH procedure (an econometric process) captures fluctuations or volatility associated with a base variable as a measure of uncertainty; for instance, macroeconomic uncertainty variable is derived from the volatility associated with GDP growth. It is important to note that this process of deriving macroeconomic uncertainty from GDP growth is a well-accepted econometric procedure in the finance and economics literature. Using this econometric framework $(G A R C H(1,1)$, inflation uncertainty and macroeconomic uncertainty variables are modeled based on the following equation:

$$
h_{t}=\omega+\alpha h_{t-1} \varepsilon_{t-1}^{2}+\beta h_{t-1} .
$$

Where $h_{t}$ captures volatility associated with each base variables analyzed

To verify the extent to which noted macroeconomic conditions influence selected performance indicators over the period under consideration, we employ seemingly unrelated regression (SUR) framework in our empirical analysis. SUR framework is adopted because of the high likelihood of correlated error terms among the various explanatory variables employed in the study. Prior to this empirical test, however, a preliminary correlation matrix examining associations between key performance indicators and modeled macroeconomic conditions is presented.

\subsection{Correlations analysis: macroeconomic conditions and bank performance indicators}

Table 2 examine how various macroeconomic conditions correlates with key bank performance indicators in the US banking sector. This correlation analysis is meant to provide preliminary overview of the core relationships if any, between the various macroeconomic conditions and bank performance indicators. It is critical to point out that this correlation analysis only highlights the nature of association between the variables being examined and does not necessarily carry any potential causal inference; such determination is made in later empirical analysis using the SUR framework. The first three columns of Table 2 exhibits fundamental association between ROA, ROE and NIM and the various macroeconomic conditions.

Correlation results presented in the first three columns of Table 2 suggest that among the various macroeconomic variables examined, three have similar significant association with ROA and ROE. The results suggest that inflation expectations, inflation uncertainty and macroeconomic uncertainty tend to have significant association with ROA and ROE, respectively. Estimates on similar association between the various macroeconomic conditions and NIM show a slightly divergent outcome with inflation uncertainty, 
macroeconomic uncertainty and inflation, rather than inflation expectations having significant association with NIM.

\section{Macroeconomic conditions and the US banking sector performance: a SUR estimation analysis}

6.1 Model specification: SUR estimation

To examine dynamic associations proposed earlier, this research employs SUR model. SUR framework features a generalization of basic linear regression model made up of multiregression equations. Each of the equations in the framework has its own dependent variable and similar or varying sets of exogenous explanatory variables. The choice of this econometric procedure has been influenced by the likelihood of correlated error terms between modeled adverse macroeconomic conditions and selected bank performance indicators in an equation system. Seemingly unrelated regressions procedure allows for the estimation of such multiple equations simultaneously while accounting for correlated or potential correlated errors. The likelihood that various bank performance indicators might significantly reflect ebbs and flows of conditions in the broader business environment (macroeconomic conditions) increases the potential for the presence of correlated error terms; in such scenario, SUR framework has been found to be the best fit in handling such estimation process. In addition, it has been found that by combining information from different equations with correlated errors, some measure of efficiency in estimation is gained over a model like the ordinary least square. According to Moon and Perron (2006), one of the appealing features of the SUR framework is the ability to impose and/or test restrictions that involve parameters in different equations. Baltagi (2005) further suggests that when errors terms between systems of equations are correlated, the SUR estimator tends to be more efficient in analyzing relationships between variables in the system of equations.

The SUR model proposed by Zellner (1962) involves examining relationships among individual variables that are linked together by contemporaneous cross-equation error correlation. This SUR method employs sets of regression equations with cross-equation parameter restrictions and correlated error terms with differing variances. Following approach adopted by Tan and Floros (2014), projected associations between various macroeconomic conditions and banking sector performance indicators are estimated using the following equations:

$$
\begin{aligned}
\mathrm{ROA}_{t} & =\beta_{0}+\beta_{1} \text { Macrounc }_{t}+\beta_{2} \text { Influnc }_{t}+\beta_{3} \text { Recprob }_{t}+\beta_{4} \operatorname{Infexp}_{t}+\beta_{5} \operatorname{Infl}_{t}+\varepsilon_{t} \\
\mathrm{ROE}_{t} & =\lambda_{0}+\lambda_{1} \text { Macrounc }_{t}+\lambda_{2} \text { Influnc }_{t}+\lambda_{3} \text { Recprob }_{t}+\lambda_{4} \operatorname{Infexp}_{t}+\lambda_{5} \operatorname{Infl}_{t}+\varepsilon_{t} \\
\mathrm{NIM}_{t} & =\gamma_{0}+\gamma_{1} \text { Macrounc }_{t}+\gamma_{2} \text { Influnc }_{t}+\gamma_{3} \text { Recprob }_{t}+\gamma_{4} \operatorname{Infexp}_{t}+\gamma_{5} \operatorname{Infl}_{t}+\varepsilon_{t}
\end{aligned}
$$

\begin{tabular}{lcrllllll}
\hline & ROA & ROE & NIM & Inflation & Inflexp & Recprob & Influnc & Macrounc \\
\hline ROA & 1 & & & & & & & \\
ROE & & 1 & & & & & & \\
NIM & & & 1 & & & & & \\
Infl & -0.057 * & 0.0966 & $0.271^{* *}$ & 1 & & & & \\
Infexp & $-0.270^{* *}$ & $-0.195^{*}$ & -0.0696 & $0.580^{* * *}$ & 1 & & & \\
Recprob & 0.102 & 0.0816 & -0.0716 & $0.184^{* *}$ & 0.149 & 1 & & \\
Influnc & $-0.267^{* *}$ & $-0.285^{* *}$ & $-0.204^{*}$ & $-0.238^{* *}$ & -0.125 & -0.0456 & 1 & \\
Macrounc & $-0.453^{* * *}$ & $-0.442^{* * * *}$ & $-0.236^{* *}$ & -0.168 & -0.0913 & -0.0599 & $0.687^{* * * *}$ & 1
\end{tabular}

Note(s): ${ }^{*} p<0.05,{ }^{* * *} p<0.01,{ }^{* * * *} p<0.001$ (asterisks denotes levels of significance at various alpha levels)

Table 2. Correlation matrix (ROA, ROE, NIM and macroeconomic conditions) 
EJMBE 29,3

\section{6}

Where $t$ subscript captures the time dimension; $\beta_{0}, \lambda_{0}, \gamma_{0}$ represent the constant terms and $\beta_{1 \ldots .} \beta_{5}, \lambda_{1} \ldots . \lambda_{5}$ and $\gamma_{1} \ldots \gamma_{5}$ represent the various coefficients. Macrounc, influnc, recprob, inflexp and infl captures various macroeconomic conditions namely, macroeconomic uncertainty, inflation uncertainty, recessionary probability, inflation expectations and inflation. Finally, ROA, ROE and NIM captures the three performance indicators.

To examine how proposed macroeconomic conditions influence key dependent variables via the SUR method, we first examine stationary features of the various variables. This preestimation procedure helps in verifying whether time series or historical data employed in subsequent empirical analysis has stationary trend or otherwise; this distinction is crucial in enhancing the accuracy of final empirical results. In the following section, stationarity characteristics associated with individual variables are examined using both the augmented Dickey-Fuller unit root test and Dickey-Fuller generalized least square test, respectively.

\subsection{Unit root tests}

Unit root test examines stability or stationary conditions associated with time series variables. Results of these tests are presented in Table 3. In performing these tests, an optimum lag order for the estimation is first determined. Lag orders in this instance are estimated using both the Akaike information criterion (AIC) and Schwarz Bayesian information criterion (SBC) procedures. Augmented Dickey-Fuller (1981) (ADF) and the Dickey-Fuller generalized least square unit root tests proposed by (Elliott et al. (1996)) are conducted simultaneously to verify stationary characteristics of study variables. Unit root features of the various variables are examined using the following equation:

$$
\Delta Z_{t}=\mu+\gamma Z_{t-1}+\sum_{j=1}^{p} \alpha_{j} \Delta Z_{t-j}+\beta t+\omega_{t}
$$

Reported results suggest that most of the variables employed are stationary for the analysis to be performed in subsequent sections with few exceptions. Nonstationary variables in this instance are taking through the proper statistical procedure (differencing process) before the final empirical tests.

\section{Effects of adverse macroeconomic conditions on the US banking sector performance}

\subsection{Empirical tests and result analysis}

This section presents and analyzes empirical tests on the extent to which modeled adverse macroeconomic conditions influence key performance indicators associated with the US

Table 3.

Unit root test: stationary analysis

\begin{tabular}{|c|c|c|c|c|c|}
\hline \multirow[b]{2}{*}{ Variables } & \multicolumn{3}{|c|}{ Augmented Dickey-Fuller test } & \multicolumn{2}{|c|}{ DF-GLS test } \\
\hline & $\begin{array}{l}\text { Optimum } \\
\text { Lag order }\end{array}$ & $\begin{array}{c}\text { Test } \\
\text { Statistic }\end{array}$ & Results & $\begin{array}{c}\text { DF-GLS } \\
\text { Test stats }\end{array}$ & Results \\
\hline Macrounc & 1 & $-4.58^{* * * *}$ & $\mathrm{I}(0)$ & $-4.99 * * *$ & $\mathrm{I}(0)$ \\
\hline Influnc & 1 & $-9.13^{* * * *}$ & $\mathrm{I}(0)$ & $-7.06^{* * * *}$ & $\mathrm{I}(0)$ \\
\hline Recprob & 1 & $-8.07 * * *$ & $\mathrm{I}(0)$ & $-7.60^{* * * *}$ & $\mathrm{I}(0)$ \\
\hline Inflexp & 1 & $-5.12 * * *$ & $\mathrm{I}(0)$ & $-4.84^{* * * *}$ & $\mathrm{I}(0)$ \\
\hline Infl & 1 & $-7.82 * * *$ & $\mathrm{I}(0)$ & $-7.16^{* * * *}$ & $\mathrm{I}(0)$ \\
\hline Roa & 1 & $-2.50 * * *$ & $\mathrm{I}(1)$ & $-2.07 * * *$ & I(I) \\
\hline Roe & 1 & $-3.04 * * *$ & $\mathrm{I}(0)$ & $-2.52^{* * * *}$ & I(I) \\
\hline $\mathrm{Nim}$ & 1 & $-0.75^{* * *}$ & $\mathrm{I}(1)$ & $-1.30^{* * *}$ & I(I) \\
\hline
\end{tabular}

Note(s): ${ }^{*} p<0.05,{ }^{* * *} p<0.01,{ }^{* * * *} p<0.001$ (asterisks denotes levels of significance at various alpha levels) 
banking sector. Three equation systems (Eqs (2)-(4)) representing the three banking sector performance indicators are presented. SUR equations examining theorized interactions are examined based on these three equation systems. The first of these equation systems (1) from Table 4 test a scenario where ROA, ROE and NIM are examined simultaneously in one equation system with all the explanatory variables. The second system (2) test similar interactions in an equation system involving ROA, ROE and NIM; however, in this scenario an assumption that inflation and inflation uncertainty might not necessarily exist at the same time (a reflection of ongoing theoretical debate) is applied. Inflation uncertainty variable is omitted in this second equation system to ascertain if significant interaction effect exist in how the variables influence performance indicators. Suppressing the influence of inflation uncertainty variable in the second SUR system is based on an ongoing debate suggesting that a macroeconomic environment already characterized by inflationary pressures cannot be said to grapple with inflation uncertainty. The argument in support of this position stems from the assumption of rationality or rational behavior on the part of economic agents (investors, consumers, firms, etc). Rationality assumption advances that rational economic agents in a macroeconomic environment adjust behavior or operational activities to prevailing macroeconomic conditions using all available information. This adjustment process helps economic agents reduce uncertainty associated with prevailing macroeconomic conditions. In order words, in inflationary macroeconomic environment, economic agents will adjust and adapt to the prevailing condition, and in the process reduce the uncertainty associated with the condition or phenomenon. Consequently, inflation and inflation

\begin{tabular}{|c|c|c|c|}
\hline & (1) & (2) & (3) \\
\hline \multicolumn{4}{|l|}{$R O A$} \\
\hline Macrounc & $-0.362^{* * * * *}(0.092)$ & $-0.350^{* * * *}(0.0613)$ & $-0.364^{* * * *}(0.0924)$ \\
\hline Influnc & $0.00919(0.053)$ & & $0.00412(0.0526)$ \\
\hline Recprob & $0.00252(0.003)$ & $0.00277(0.0029)$ & $0.00238(0.0033)$ \\
\hline Inflexp & $-0.269^{* * * * *}(0.0689)$ & $-0.271^{* * * *}(0.0680)$ & $-0.237^{* * * *}(0.0581)$ \\
\hline Infl & $0.0577(0.067)$ & $0.0564(0.0665)$ & \\
\hline cons & $1.928^{* * * *}(0.190)$ & $1.933^{* * * * *}(0.188)$ & $1.870^{* * * * * *}(0.178)$ \\
\hline $\bar{R}^{2}$ & 0.3103 & 0.3103 & 0.3065 \\
\hline \multicolumn{4}{|l|}{$R O E$} \\
\hline Macrounc & $-3.934^{\text {**** }}(1.075)$ & $-3.787^{* * * *}(0.760)$ & $-4.017^{* * * * *}(1.104)$ \\
\hline Influnc & $0.132(0.615)$ & & $-0.0513(0.628)$ \\
\hline Recprob & $0.0170(0.0378)$ & $0.0201(0.034)$ & $0.0119(0.0388)$ \\
\hline Inflexp & $-3.167^{* * * *}(0.803)$ & $-3.191^{* * * *}(0.793)$ & $-2.004^{* *}(0.694)$ \\
\hline Infl & $2.085^{* *}(0.780)$ & $2.069^{* *}(0.776)$ & \\
\hline cons_ & $21.56^{* * * *}(2.216)$ & $21.62^{* * * *}(2.199)$ & $19.46^{* * * *}(2.129)$ \\
\hline$R^{2}$ & 0.2905 & 0.2905 & 0.2514 \\
\hline \multicolumn{4}{|l|}{ NIM } \\
\hline Macrounc & $-0.196(0.116)$ & $-0.190^{*}(0.077)$ & $-0.211(0.124)$ \\
\hline Influnc & $0.00491(0.067)$ & & $-0.0272(0.0708)$ \\
\hline Recprob & $-0.00220(0.0041)$ & $-0.0021(0.0037)$ & $-0.0031(0.0044)$ \\
\hline Inflexp & $-0.259^{* * *}(0.0870)$ & $-0.260^{* *}(0.0858)$ & $-0.0548(0.0782)$ \\
\hline Infl & $0.366^{* * * * *}(0.0845)$ & $0.365^{* * * *}(0.0840)$ & \\
\hline _cons & $4.480^{* * * * *}(0.240)$ & $4.482^{* * * *}(0.238)$ & $4.112^{* * * *}$ \\
\hline $\bar{R}^{2}$ & 0.1896 & 0.1896 & 0.0719 \\
\hline$N$ & 129 & 129 & 129 \\
\hline
\end{tabular}

Note(s): Standard errors in ( ) ${ }^{*} p<0.05,{ }^{* * *} p<0.01,{ }^{* * *} p<0.001$ (asterisks denotes levels of significance at various alpha levels)

\section{The US banking sector}

Table 4 Effects of adverse macroeconomic conditions on bank performance 
EJMBE 29,3

248

uncertainty may not necessarily prevail at the same time. In support of this position, Pourgerami and Maskus (1987) pointed out that in an environment of accelerating inflation, economic agents tend to invest more resources in inflation forecasting with the prime goal of reducing uncertainty. Finally, a third system (3) made up of ROA, ROE and NIM with all the adverse macroeconomic conditions with the exception of inflation is also tested. This final test is performed to ascertain effects of a reversal of the condition tested in the second equation system. An in-depth explanation of the rationale for the omission of the variables in scenarios two and three are presented in our analysis of estimated empirical results. Table 4 presents SUR coefficients estimates of how various adverse macroeconomic conditions examined in the study influence variability in bank performance indicators among the US banks.

\subsection{Empirical analysis: adverse macroeconomic conditions and key performance indicators in the US banking sector}

Empirical results presented in the first column of Table 4 are based on SUR equation system featuring three bank performance indicators and the various explanatory variables. Entire results presented in Table 4 suggest that significant differences exist in how various adverse macroeconomic conditions examined influence performance indicators in the US banking sector over the period examined. Coefficient estimates reported in the first column of Table 4, for instance, suggest that among the five macroeconomic conditions examined, only inflation expectations and macroeconomic uncertainty have significant influence on variability in ROA in the US banking sector over the study period. Both inflation expectations and macroeconomic uncertainty have negative influence on ROA. As surmised earlier, these negative results suggest that the two macroeconomic conditions have constraining effect on growth in ROA in the US banking sector; between the two macroeconomic conditions, however, macroeconomic uncertainty is found to have more constraining impact on ROA than inflation expectations all things being equal. In this same first scenario (first column of Table 4), inflation, recession probability/expectations and inflation uncertainty are found to be insignificant in explaining any form of variability associated with ROA; at least within the time frame being examined.

In the second part of the same SUR system (first column of Table 4), reported coefficient estimates further suggest similar association between the same two macroeconomic conditions and ROE. Estimated results suggest that these two adverse macroeconomic conditions have similar significant negative impact on $\mathrm{ROE}$, but with a much greater constraining effect comparatively. Negative coefficients, in this instance, suggest the two macroeconomic conditions (macroeconomic uncertainty and inflation expectations) have encumbering effect on return on equity in the US banking sector. An in-depth analysis of the raw data on ROA and ROE suggests that ROE data are characterized by more volatility than ROA. It is thus probable to surmise that this characteristic might have contributed to the relatively high coefficient estimates associated with ROE. Presented coefficient estimates further suggest that once again macroeconomic uncertainty tends to have a much more constraining impact on ROE than inflation expectations holding all else constant. In addition to these two adverse macroeconomic conditions, our results also show that inflation has significant effects on ROE. Contrary to the nature of influence observed from the other two macroeconomic conditions, this result suggest prevailing inflationary conditions rather has positive impact on ROE in the US banking sector; a condition consistent with findings of Athanasoglou et al. (2005) and Flamini et al. (2009) respectively.

The last section of column 1 of Table 4 presents test results focusing on how modeled macroeconomic conditions affects net interest margins in the US banking sector. The results in this instance suggest that among the macroeconomic conditions examined, only inflation 
expectations has significant positive impact on NIMs (a measure of operational efficiency). This positive coefficient to some degree suggests that firms in the US banking sector tend to enhance operational efficiency in anticipation of inflationary pressures; a condition, which reflects pre-emptive measures firms or banks ordinarily adopts in hopes of minimizing vulnerability to projected/anticipated adverse macroeconomic conditions.

Coefficient estimates presented in the second column (2) of Table 4 revolves around the assumption that inflation uncertainty may not constitute a threat to key economic agents or firms in a macroeconomic environment already characterized by inflationary conditions. Based on this contention, inflation uncertainty variable is omitted in this second stage of testing to ascertain effects of such omission on how bank performance indicators interacts with the remaining macroeconomic conditions. Coefficient estimates based on this assumption suggest that effects are similar to those presented in column 1 with minimal variations. Results in this instance suggest inflation expectations and macroeconomic uncertainty have significant (negative) constraining impact on ROA even in the absence of inflation uncertainty concerns. In addition, reported coefficient estimates further suggest that effects of modeled adverse macroeconomic conditions on ROE in the absence of inflation uncertainty are not significantly different from that of the first results presented in column 1 of Table 4. Coefficient estimates in this case suggest that unlike results from ROA, three out of the five macroeconomic conditions examined affects variability in ROE, with inflation again having divergent (positive) impact compared to macroeconomic uncertainty and inflation expectations. Negative coefficients in this regard indicate such macroeconomic conditions constrain growth in ROE. Results presented in the last part of column 2 of Table 4 examine how various macroeconomic conditions influence NIM in an environment devoid of inflationary uncertainty. On this test, we find that the omission of inflation uncertainty variable impacts how macroeconomic uncertainty affects NIM. The result shows that in the absence of inflation uncertainty, macroeconomic uncertainty variable becomes significant; with a negative or constraining impact on NIM. This outcome suggests that inflation uncertainty to some degree has significant interaction with macroeconomic uncertainty.

The final column (3) of Table 4 presents similar empirical results based on a three-tier SUR test procedure adopted in the first two; however, results reported in this column assumes a macroeconomic environment devoid of inflationary conditions. Coefficient estimates in this instance suggest that in the absence of actual inflationary conditions macroeconomic uncertainty and inflation expectations still have significant negative influence on ROA. This result affirms similar negative/constraining effects reported in the first two instances; however, a critical examination of the results further suggest that constraining effects of inflation expectations on the various performance indicators are minimal compared to the first two instances. Estimated results on the effects of various macroeconomic conditions on $\mathrm{ROE}$ on the other hand suggest that in an environment devoid of actual inflation pressures, negative/constraining effects of macroeconomic uncertainty tend to be relatively stronger; this is evidenced by a much higher coefficient of $(-4.017)$ compared to coefficients from the first two scenarios (-3.934) and (-3.787), respectively. In addition, the results further suggest that effects of inflation expectations on ROE also tend to diminish significantly in a macroeconomic environment not characterized by inflationary pressures. In the final part of column 3 where similar scenario is examined, the dominant interaction role of inflation becomes apparent. The results in this instance suggest that in the absence of inflationary condition, all other conditions examined become insignificant in explaining variability in NIM. This result to some extent builds on ongoing economic debate on the relationships among inflation, inflation expectations and inflation uncertainty. Presented empirical results suggest a significant link or association among these strands of inflationary conditions. The absence of inflationary condition in the last part of column 3 automatically negated effects of other strands of inflationary conditions in the test. This condition seems to support the view 
EJMBE 29,3

that inflationary condition and inflation expectations may not prevail simultaneously in a macroeconomic environment. In order words, inflation expectations might not be an issue for an economy already experiencing inflation. In a seminal speech in support of this association, Bernanke (2004) alluded to this relationship by suggesting a significant nexus between inflation and inflation expectations. In a statement on the link between inflation and inflation expectations, Bernanke (2004) noted "An essential prerequisite to controlling inflation is controlling inflation expectations"; this statement to some extent suggests that realized or ongoing inflation has a significant relationship with inflation expectations. It further suggest that it may be an economic oddity for inflation expectations to be perceived as a problem in an environment already characterized by inflationary pressures. Our results on how omission of inflation influences how other variables influenced NIM in this instance support a known macroeconomic phenomenon about the interactions among these three strands of inflationary conditions.

From the above empirical results, it is evident that strands of inflationary conditions and other macroeconomic conditions such as those examined exerts varying significant effects on performance in the US banking sector. Test results further show that individual adverse macroeconomic conditions tend to have divergent impact on different bank performance indicators in different scenarios. Presented empirical results further support the notion that different banking sector performance indicators respond differently to adverse macroeconomic conditions; for instance, results presented in Table 4 suggest that ROE seems to be impacted more by macroeconomic uncertainty and inflation expectations than the ROA and NIM. The results also show that various adverse macroeconomic conditions examined seems to have less impact on net interest margin compared to ROA and ROE.

\section{Conclusion and potential policy implications}

This study examined effects of strands of related inflationary conditions and other macroeconomic conditions (macroeconomic uncertainty, inflationary uncertainty, recession probability, inflation expectations and inflation) on selected performance indicators in the US banking sector. Effects of various macroeconomic conditions on the US banking sector performance were examined empirically using SUR framework. Empirical results presented based on three test scenarios suggest that among adverse macroeconomic conditions examined, macroeconomic uncertainty and inflation expectations have significant negative impact on banking sector performance indicators at various alpha levels. For instance, in all three scenarios examined, we find that macroeconomic uncertainty and inflation expectations tend to constrain growth in both ROA and ROE in the US banking sector over the period examined. In addition, coefficients estimates further suggest that among bank performance indicators examined, macroeconomic uncertainty and inflation expectations have relatively much more constraining impact on ROE than the ROA and NIM. Again, empirical estimates presented in Table 4 also show that among the performance indicators examined, NIM is the variable least impacted by the various macroeconomic conditions examined.

Findings presented above could help inform strategic planning decisions pursued by institutions in the banking sector. For instance, some of the findings could inform policies and operational strategies geared toward reducing vulnerability associated with specific performance indicators such as ROE. This could be achieved by critically examining how individual performance indicators react to specific adverse macroeconomic condition. This process could help develop tailored measures or procedures focusing on reducing how susceptible key performance indicators are to the various adverse macroeconomic conditions. Other findings could also provide the platform for more adaptive policies aimed at minimizing effects of macroeconomic conditions on operational efficiency in the banking sector. Finally, we are of the view that further studies focusing on how other unexamined 
adverse macroeconomic conditions such as equity market related uncertainty impacts banking sector performance could help strengthen the literature on how the banking industry reacts to adverse macroeconomic conditions.

\section{References}

Aburime, T. (2008), "Determinants of bank profitability: macroeconomic evidence from Nigeria", International Journal of Nigerian Studies and Development, Vol. 14, pp. 21-34, doi: 10.2139/ssrn. 1231064.

Aggarwal, R., Inclan, C. and Leal, R. (1999), "Volatility in emerging stock markets", Journal of Financial and Quantitative Analysis, Vol. 34 No. 1, pp. 33-55, doi: 10.2307/2676245.

Akgül, I. and Sayyan, H. (2005), "Forecasting Volatility in ISE-30 stock returns with asymmetric conditional Heteroscedasticity models", Symposium of Traditional Finance, Marmara Universitesi Bankacilk ve Sigortacılk Yüksekokulu, Istanbul, Turkey.

Akhavein, J.D., Berger, A.N. and Humphrey, D.B. (1997), "The effects of megamergers on efficiency and prices: evidence from a bank profit function", Board of Governors of the Federal Reserve System, Finance and Economic Discussion Series 9.

Al-Homaidi, E.A., Tabash, M.I., Farhan, N.H.S. and Almaqtari, F.A. (2018), "Bank-specific and macroeconomic determinants of profitability of Indian commercial banks: a panel data approach", Cogent Economics and Finance, Vol. 6 No. 1, p. 1548072, doi: 10.1080/23322039.2018.1548072.

Angori, G., Aristei, D. and Gallo, M. (2019), "Determinants of banks' net interest margin: evidence from the euro area during the crisis and post-crisis period", Sustainability 2019, Vol. 11 No. 14, p. 3785 , doi: $10.3390 /$ su11143785.

Athanasoglou, P.P. and Brissimis, S.N. and Delis, M.D. (2008), "Bank-specific, industry-specific and macroeconomic determinants of bank profitability", Journal of International Financial Markets, Institutions and Money, Elsevier, Vol. 18 No. 2, pp. 121-136.

Ayaydin, H. and Karakaya, A. (2014), "The effect of bank capital on profitability and risk in Turkish banking", International Journal of Social Science, Vol. 5 No. 1, pp. 252-271.

Baltagi, B. (2005), Econometric Analysis of Panel Data, 3rd ed., John Wiley \& Sons, New York.

Batten, J. and Xuan Vinh Vo (2019), "Determinants of bank profitability — evidence from Vietnam", Emerging Markets Finance and Trade, Vol. 55 No. 6, pp. 1417-1428, doi: 10.1080/1540496X.2018. 1524326.

Baum, C., Caglayan, M. and Ozkan, N. (2005), The Second Moments Matter: The Response of Bank Lending Behavior to Macroeconomic Uncertainty, Boston College, Working Paper, p. 521.

Bekaert, G. and Harvey, C.R. (1997), "Emerging equity market volatility", Journal of Financial Economics, Vol. 43, pp. 29-77, doi: 10.1016/S0304-405X(96)00889-6.

Bernanke, B. (2004), "The economic outlook and monetary policy", Speech at the Bond Market Association Annual Meeting, New York.

Bollerslev, T. (1986), "Generalized autoregressive conditional heteroskedasticity", Journal of Econometrics, Vol. 31 No. 3, pp. 307-327.

Bordeleau, E. and Graham, C. (2010), The Impact of Liquidity on Bank Profitability, Working Paper, Bank of Canada.

Bourke, P. (1989), "Concentration and other determinants of bank profitability in Europe, North America and Australia", Journal of Banking and Finance, Vol. 13 No. 1, pp. 65-79.

Demir, F. (2009), "Financialization and manufacturing firm profitability under uncertainty and macroeconomic volatility: evidence from an emerging market", Review of Development Economics, Vol. 13 No. 4, pp. 592-609, doi: 10.1111/j.1467-9361.2009.00522.

Demirguc-Kunt, A. and Huizinga, H. (1999), "Determinants of commercial bank interest margins and profitability: some international evidence", The World Bank Economic Review, Vol. 13 No. 2, pp. 379-408. 
EJMBE 29,3

Elliott, G., Rothenberg, T.J. and Stock, J.H. (1996), "Efficient tests for an autoregressive unit root", Econometrica, Vol. 64, pp. 813-836.

Engle, R.F. (1982), "Autoregressive conditional heteroskedasticity with estimates of the variance of U.K. inflation”, Econometrica, Vol. 50, pp. 987-1008.

Fang, J., Lau, C.K., Lu, Z., Tan, Y. and Zhang, H. (2019), "Bank performance in China: a perspective from bank efficiency, risk-taking and market competition”, Pacific-Basin Finance Journal, Vol. 56, pp. 290-309.

Flamini, V., McDonald, C.A. and Schumacher, L. (2009), "The determinants of commercial bank profitability in Sub-Saharan Africa (EPub)", International Monetary Fund, Vol. 9.

Francis, M.E. (2013), "Determinants of commercial bank profitability in Sub-Saharan Africa", International Journal of Economics and Finance, Vol. 5 No. 9, pp. 134-147.

Garcia-Herrero, A., Gavila, S. and Santa barbara, D. (2009), "What explains the low profitability of Chinese banks?", Journal of Banking and Finance, Vol. 33 No. 11, pp. 2080-2092.

Gökbulut, R. and Pekkaya, M. (2014), "Estimating and forecasting volatility of financial markets using asymmetric GARCH models: an application on Turkish financial markets", International Journal of Economics and Finance, Vol. 6 No. 4, pp. 23-33, doi: 10.5539/ijef.v6n4p23.

Guru, B., Staunton, J. and Balashanmugam, B. (2002), "Determinant of commercial bank profitability in Malaysia", Paper Presented at the 12th Annual Australian Finance and Banking Conference Sydney, Australia, 16 - 17 December.

Heffernan, S. and Fu, M. (2008), "The determinants of bank performance in China”, (August 22, 2008). doi: 10.2139/ssrn.1247713.

Khan, M., Yousaf, M., Wadood, A., Junaid, M., Ashraf, M., Alam, U., Ali, M., Arshad, M., Hussain, Z. and Khan, K.M. (2014), "Impacts of inflationary trends on banks' performance (large banks segment) in Pakistan", International Journal of Accounting and Financial Reporting, Vol. 4 No. 1, 2014, pp. 2162-3082.

Kohlscheen, E., Murcia, A. and Contreras, J. (2018), "Determinants of bank profitability in emerging markets”, BIS Working Paper. No. 686, available at: https:/www.bis.org/publ/work686.pdf.

Marinkovic, S. and Radovic, O. (2014), "Bank net interest margin related to risk, ownership and size: an exploratory study of the Serbian banking industry", Economic Research-Ekonomska Istraživanja, Vol. 27 No. 1, pp. 134-154, doi: 10.1080/1331677X.2014.952114.

Moguillansky, G. (2002), "Investment and financial volatility in Latin America", CEPAL Review, Vol. 77, pp. 45-63.

Moon, H.R. and Perron, B. (2006), Seemingly Unrelated Regressions, The New Palgrave Dictionary of Economics.

Nier, E. and Zicchino, L. (2005), Bank Weakness and Bank Loan Supply, Bank of England Financial Stability Review, pp. 85-93.

Petriaa, N., Caprarub, B. and Ihnatovc, I. (2015), "Determinants of banks' profitability: evidence from EU 27 banking systems", Procedia Economics and Finance, Vol. 20 No. 2015, pp. 518-524.

Pasiouras, F. and Kosmidou, K. (2007), "Factors influencing the profitability of domestic and foreign commercial banks in the European Union", Research in International Business and Finance, Vol. 21 No. 2, pp. 222-237.

Pourgerami, A. and Maskus, K. (1987), "The effects of inflation on the predictability of price changes in Latin America: some estimates and policy implications", World Development, Vol. 15 No. 2, pp. 287-290.

SahyounI, A. and Wang, M. (2018), "The determinants of bank profitability: does liquidity creation matter?", Journal of Economics and Financial Analysis, Vol. 2 No. 2, pp. 61-85, available at: https://ojs.tripaledu.com/index.php/jefa/article/view/30/38. 
Saeed, M.S. (2014), "Bank-related, industry-related and macroeconomic factors affecting bank profitability: a case of the United Kingdom", Research Journal of Finance and Accounting, Vol. 5 No. 2.

Sidabalok, Louvti Rodney and, D. and Viverita (2011), "The determinants of net interest margin in the Indonesian banking sector", (August 26, 2011). doi: 10.2139/ssrn.1917367.

Smirlock, M. (1985), "Evidence on the (non) relationship between concentration and profitability in banking", Journal of Money, Credit, and Banking, Vol. 17, pp. 69-83.

Sufian, F. and Chong, R.R. (2008), "Determinants of bank profitability in a developing economy: empirical evidence from the Philippines", Asian Academy of Management Journal of Accounting and Finance, Vol. 4 No. 2, pp. 91-112.

Talavera, et al. (2006), Macroeconomic Uncertainty and Bank Lending: The Case of Ukraine, German Institute for Economic Research, Discussion Paper Series 637. November, pp. 1-24.

Tan, Y. and Floros, C. (2012), "Bank profitability and inflation: the case of China", Journal of Economics Studies, Vol. 39, pp. 675-696.

Tan, Y. and Floros, C. (2014), "Risk, profitability and competition: evidence from the Chinese banking industry", Journal of Developing Areas, Vol. 48, pp. 303-319.

Vensel, V., Aarma, A. and Vainu, J. (2004), Bank Performance Analysis: Methodology and Empirical Evidence: Estonian Banking System, 1994-2002. Working Paper Series.

Zellner, A. (1962), "An efficient method of estimating seemingly unrelated regression equations and tests of aggregation bias", Journal of the American Statistical Association, Vol. 57, pp. 500-509.

\section{Further reading}

Erlend, N. and Lea, Z. (2005), Bank Weakness and Bank Loan Supply, Financial Stability Review Bank of England, pp. 85-92.

Zellner, A (1963), "Estimators for seemingly unrelated regression equations: some finite sample results", Journal of the American Statistical Association, Vol. 58 No. 304, pp. 977-992, (Dec., 1963).

\section{Corresponding author}

Rexford Abaidoo can be contacted at: rabaidoo@umes.edu

For instructions on how to order reprints of this article, please visit our website:

www.emeraldgrouppublishing.com/licensing/reprints.htm

Or contact us for further details: permissions@emeraldinsight.com 